\title{
Characteristics of relocated hypocenters of the 2018 M6.7 Hokkaido Eastern Iburi earthquake and its aftershocks with a three-dimensional seismic velocity structure
}

\author{
Saeko Kita* ${ }^{*}$
}

\begin{abstract}
I relocated the hypocenters of the 2018 M6.7 Hokkaido Eastern Iburi earthquake and its surrounding area, using a three-dimensional seismic structure, the double-difference relocation method, and the JMA earthquake catalog. After relocation, the focal depth of the mainshock became $35.4 \mathrm{~km}$. As previous studies show, in south-central Hokkaido, the Hidaka collision zone is formed, and anomalous deep and thickened forearc crust material is subducting at depths of less than $70 \mathrm{~km}$. The mainshock and its aftershocks are located at depths of approximately 10 to $40 \mathrm{~km}$ within the lower crust of the anomalous deep and thickened curst near the uppermost mantle material intrusions in the northwestern edge of this Hidaka collision zone. Like the two previous large events, the aftershocks of this event incline steeply eastward and appear to be distributed in the deeper extension of the Ishikari-teichi-toen fault zone. The highly inclined fault in the present study is consistent with a fault model by a geodetic analysis with InSAR. The aftershocks at depths of 10 to $20 \mathrm{~km}$ are located at the western edge of the high-attenuation (low-Qp) zone. These kinds of relationships between hypocenters and materials are the same as the 1970 and 1982 events in the Hidaka collision zone. The anomalous large focal depths of these large events compared with the average depth limit of inland earthquakes in Japan could be caused by the locally lower temperature in south-central Hokkaido. This event is one of the approximately M7 large inland earthquakes that occurred repeatedly at a recurrence interval of approximately 40 years and is important in the collision process in the Hidaka collision zone.
\end{abstract}

Keywords: Relocations of hypocenters, The Hidaka collision zone, Hokkaido, Seismic structures

\section{Introduction}

On September 6, 2018, a large earthquake occurred in the central and eastern Iburi regions of Hokkaido, beneath the northeastern (NE) Japan arc, in NE Japan (Fig. 1). The Japan Meteorological Agency (JMA) magnitude of this event is 6.7 and its focal depth is approximately $37 \mathrm{~km}$. Based on geological investigations, the NE Japan arc meets the Kuril arc in the center of Hokkaido Island, which has collided with the Kuril forearc at the Hidaka

*Correspondence: kita@kenken.go.jp

Building Research Institute, Tatehara 1, Tsukuba 305-0802, Japan main thrust in the south-central part of Hokkaido island since the middle Miocene (Kimura 1994, 1996) (Fig. 1). The southwestward migration of the Kuril forearc sliver due to the oblique subduction of the Pacific plate is thought to be a cause of this arc-arc collision zone.

In this area, large inland earthquakes with magnitudes of approximately M7 have occurred repeatedly at intervals of approximately 40 years, including the $1931 \mathrm{Mj}$ 6.8, the $1932 \mathrm{Mj} 7.0$ (Utsu 1999; Ichikawa 1971), and two recent large events-one in 1970 and one in 1982-at depths of 20-30 km for the $1970 \mathrm{Mj} 6.7$ Hidaka earthquake (Ichikawa 1971; Moriya 1972) and 18-35 km for 

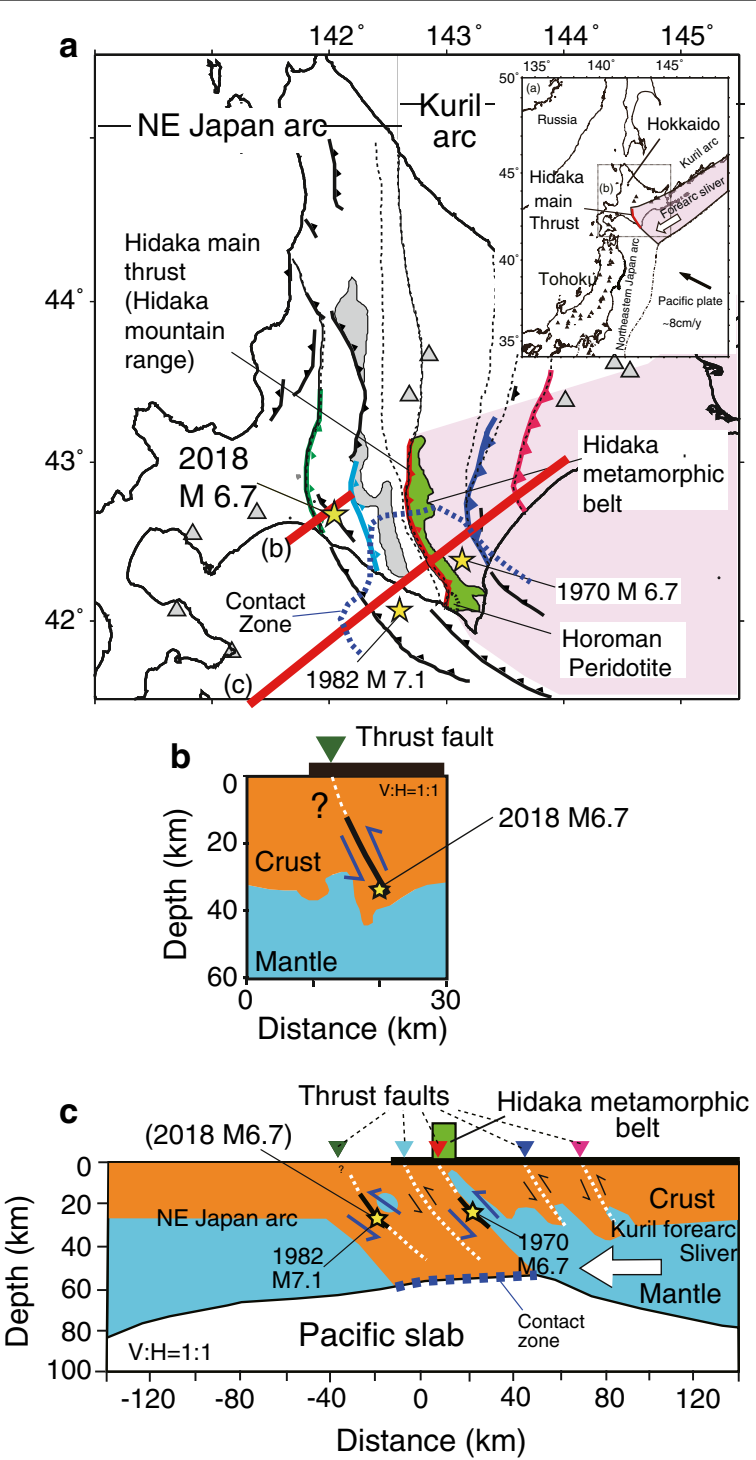

Fig. 1 a Tectonic setting of Hokkaido (modified after Kita et al. (2012), originally from Iwasaki et al. (2004), and Kimura (1994), and the Geological Survey of Japan 1992). The main plot is an enlarged image of the squared area in the inset map. The pink zone indicates the Kuril forearc. Dotted lines indicate tectonic boundaries. Thick lines with triangles denote Quaternary and Neogene thrust faults (green: Ishikari-teichi-toen fault zone; thin blue: Yubari-dake fault (Ito 2000); red: Hidaka main thrust; blue: Tokachi Plain faults: purple: Urahoro fault; black: other thrust faults). Green- and gray-shaded zones indicate the Hidaka metamorphic belt and the Kamuikotan metamorphic belt, respectively. Yellow stars indicate relocated hypocenters in the present study. Black stars indicate the hypocenters of the 1970 Hidaka and 1982 Urakawa-oki earthquakes. Triangles indicate sites of active volcanoes. The blue dashed line shows the location of the contact zone of the slab upper surface (Kita et al. 2010) with the anomalously deepened crustal materials. $\mathbf{b}$ Schematic diagram of the 2018 M6.7 event and the structure beneath south-central Hokkaido. c Schematic diagram of large inland events and the structure of the collision between the Kuril and NE Japan forearcs beneath the Hidaka collision zone

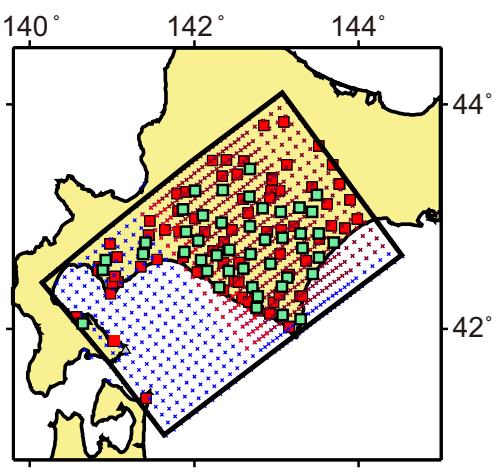

Fig. 2 Distribution of stations and grid configurations (red and blue crosses) used in the relocation by the double-difference tomography method. The relocation of the present study shown in Fig. 3 used permanent seismic stations, which are denoted as red squares. Green squares denote the temporary stations which were operated in 1999 to 2001 (Katsumata et al. 2003). Both the permanent and temporary stations were used in the estimation of the detailed seismic structure shown in Figs. 4 and 5

the $1982 \mathrm{Mj} 7.1$ Urakawa-oki earthquake (Moriya et al. 1983) (Fig. 1a). These focal depths are anomalously larger than those of typical inland crustal earthquakes in the Japanese islands ( $15 \mathrm{~km}$ Omuralieva et al. 2012).

Several seismological studies on the crustal structure of central Hokkaido have been carried out to obtain images so as to clarify the collision process of the two forearcs (Seismic surveys: Ito et al. 1999; Ito 2000; Iwasaki et al. 1998, 2004; Seismic velocity structures: Takanami 1982; Fuji and Moriya 1983; Miyamachi and Moriya 1984; Miyamachi et al. 1994; Moriya et al. 1998; Katsumata et al. 2003, 2006; Murai et al. 2003; Kita et al. 2010, 2012; Seismic attenuation structure: Furumura and Moriya 1990; Taira and Yomogida 2004; Takahashi 2012; Kita et al. 2014). Kita et al. (2012) performed high-resolution 3-D seismic velocity tomography beneath south-central Hokkaido at a spatial resolution of approximately $10 \mathrm{~km}$, by applying the double-difference tomography method (Zhang and Thurber 2003, 2006) to joint data from the dense nationwide Kiban seismic network (e.g., Okada 2004; Obara et al. 2005) and from a temporary seismic network (Katsumata et al. 2002) (as shown in Fig. 2). Their results of seismic structures indicated the inhomogeneous seismic structure related with the arc-arc collision zone process at depths of 35 to $90 \mathrm{~km}$ and explained the reason for the anomalous deep focal depths of the two large events, based on their seismic velocity structures; the results of heat flow; and geological-petrological studies (Fig. 1b).

In the determination of the hypocenter by the JMA, the routine one-dimensional seismic structure is usually applied to seismic data. In the present study, I 
relocated hypocenters using the three-dimensional seismic structure to examine the focal depth of mainshock, its relationship to previous large events, the detailed collision zone process and the tectonic setting of Hokkaido, including active faults.

\section{Data and method}

I assumed the three-dimensional seismic structure by Kita et al. (2012) and relocated hypocenters, applying the program code of the double-difference tomography method (Zhang and Thurber 2003, 2006) to the arrival time data of the events from the JMA earthquake cata$\log$. In the relocation by double-difference tomography, I fixed the seismic structure and did not fix hypocenters. The grid intervals, which were needed for assuming the $3 \mathrm{D}$ seismic structures, were set at 5 to $10 \mathrm{~km}$ in the along-arc direction, $10 \mathrm{~km}$ in the across-arc direction, and 5 to $10 \mathrm{~km}$ in the vertical direction. Grid and station distributions are shown in Fig. 2. The seismic structure used in the study is also shown in Figs. 3 and 4, and Additional file 1. Fifty-three permanent seismic stations from the Kiban network and the grid distributions are the same as in Kita et al. (2012). The initial hypocenters

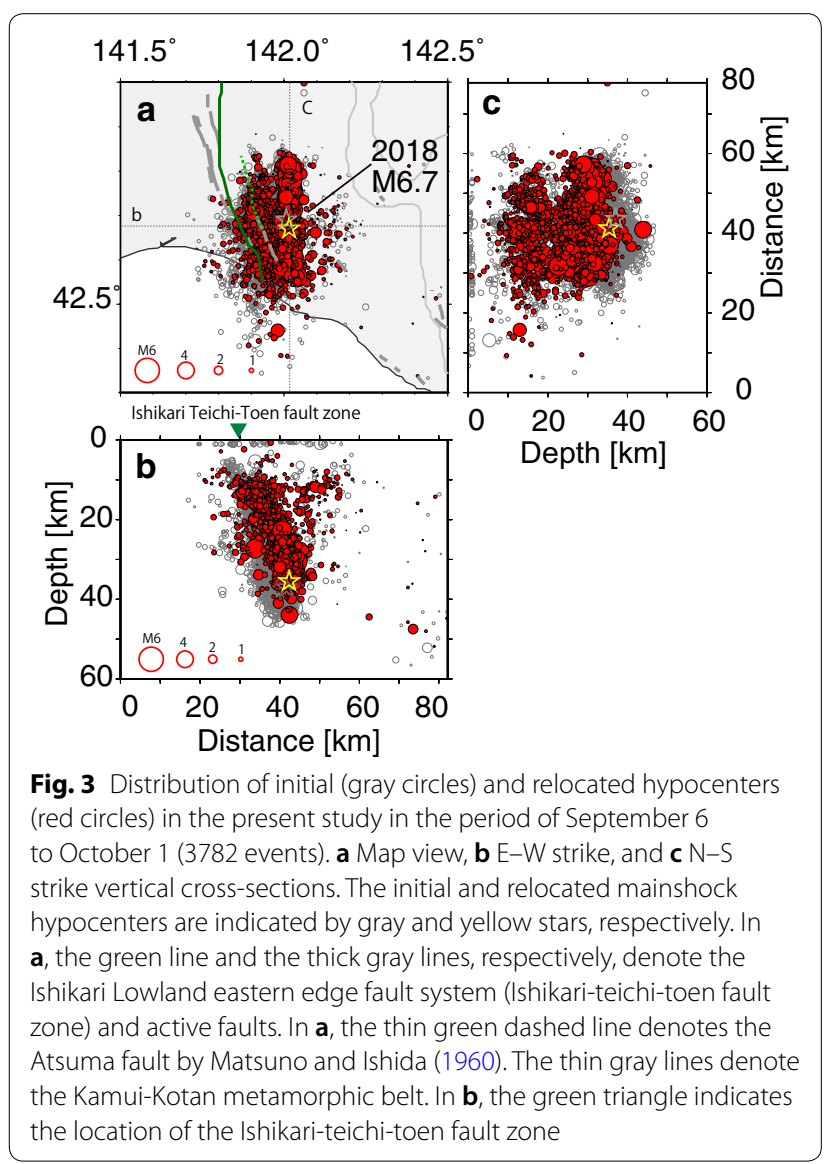

from the JMA earthquake catalog are shown in Fig. 3 as gray open circles. The seismic structures are shown in Figs. 4 and 5. For the relocation, I selected event pairs with an epicentral separation of less than $5 \mathrm{~km}$ and an epicentral distance between a station and a pair of events of less than $400 \mathrm{~km}$. I also selected events having more than eight arrival time double differences (DDs) with neighbors. The analysis period was from January 1, 2015 to October 31, 2018, and the depth range of the analyzed hypocenters was set as 0 to $100 \mathrm{~km}$. In the JMA catalog, there are three types of flags for P-waves (IP: impulsive P-wave, EP: emergent P-wave, and P: P-wave between impulsive and emergent) for reading the arrival times data. The read arrival times were weighted according to these three types of flags (IP and IS: 1.0, P and S: 0.7, and EP and ES: 0.1). A total of 64,144 arrival time differences were obtained for 85,061 P-waves from the JMA earthquake catalog, and 39,952 arrival time differences were obtained for 53,264 S-waves from the JMA earthquake catalog. Arrival time differences were obtained from the catalog, but from the cross-correlation method was not used in this analysis.

\section{Results}

In total, 5109 events were relocated. The average root mean square value of the DDs for each event was reduced by this procedure from 1.29 to $0.14 \mathrm{~s}$. Using observations with random noises corresponding to picking errors (standard deviations of $0.10 \mathrm{~s}$ for P waves and $0.20 \mathrm{~s}$ for S waves), the mean errors were estimated to be $0.65 \mathrm{~km}$ in depth and $0.54 \mathrm{~km}$ in the horizontal direction. The results for relocated hypocenters are shown in Fig. 3. The hypocenters parameters of the main shock and its aftershocks are shown in Additional file 2. After relocation, the depth of the mainshock became $35.4 \mathrm{~km}$ with estimated errors of $0.23 \mathrm{~km}$ in depth and $0.26 \mathrm{~km}$ in the horizontal direction. Comparing the depths of the relocated and initial hypocenters at depths of less than $30 \mathrm{~km}$ and those at depths of more than $30 \mathrm{~km}$, the depths of the relocation results were, respectively, $4.2 \mathrm{~km}$ and $5.1 \mathrm{~km}$ (on average) shallower than those of the initial hypocenters.

Figure 3 shows horizontal and vertical slices of the hypocenter location. The relocated mainshock is also plotted on the tectonic setting presentation figure (Fig. 1a). The mainshock and most of the aftershocks are relocated eastward of the Ishikari Lowlands (Ishikariteichi-toen) fault zone. In Fig. 3, the relocated aftershocks and mainshock are generally found at depths of 10 to $40 \mathrm{~km}$, striking in the north-south direction and inclined eastward at less than $60^{\circ}$. The relocated aftershocks and mainshock are also plotted on the seismic velocity structure (Kita et al. 2012) shown in Figs. 4a, g, and 5. The aftershocks and mainshock are located in the portions of 

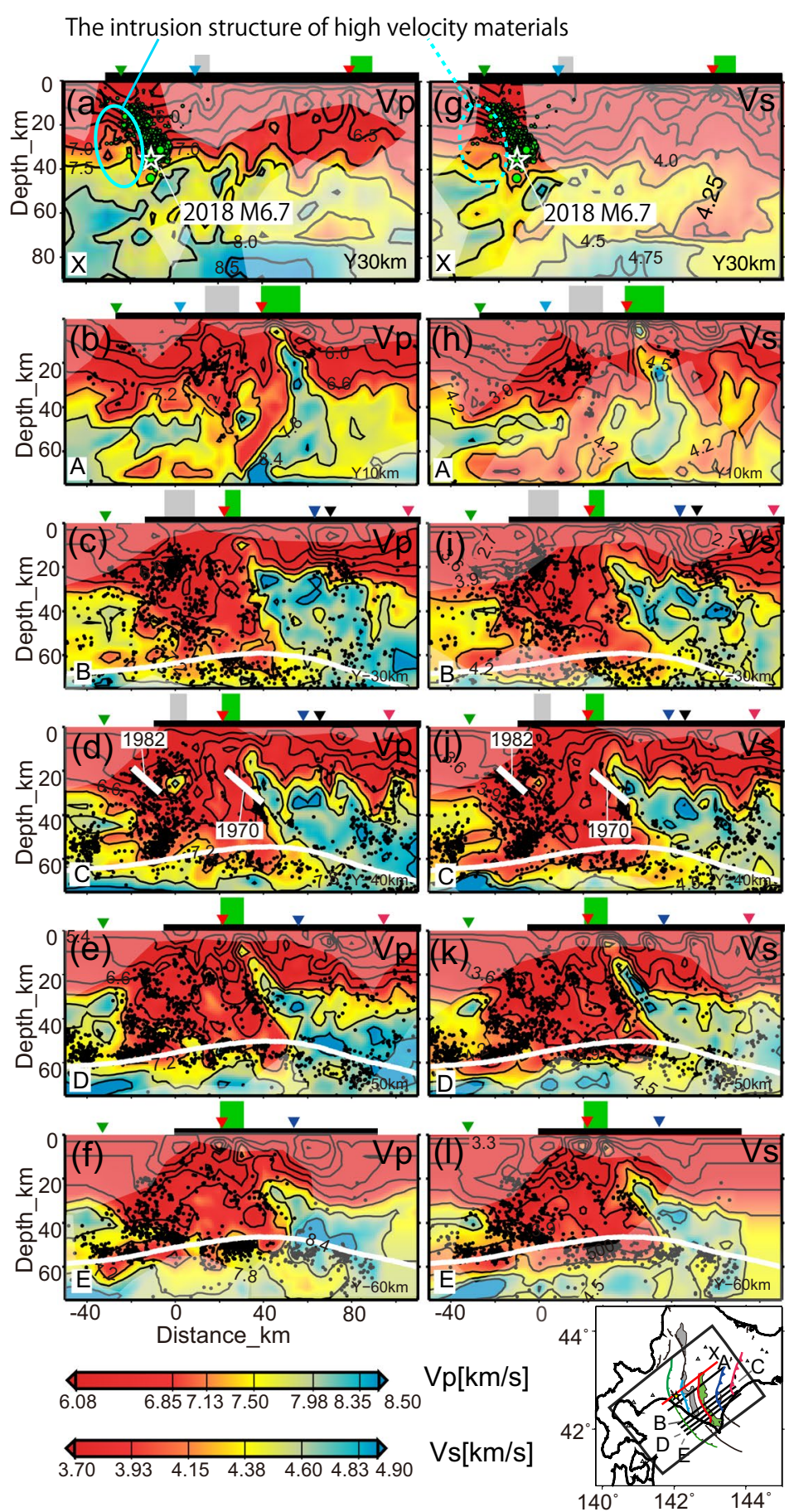

Fig. 4 Relocated hypocenters (green circles: aftershocks, white stars: mainshock) in the present study plotted on along-arc vertical cross-sections of the detailed seismic velocity structures estimated by Kita et al. (2012). Relocated hypocenters of aftershocks within $5 \mathrm{~km}$ from the vertical section were plotted. The locations of the sections are shown in the inset map. The thick white lines in $\mathbf{d}$ and $\mathbf{j}$ show the locations of the faults of the 1970 and 1982 events. (left) P and (right) S wave velocities are indicated by the color scale. Black dots indicate the hypocenters used in the tomographic inversions presented in Kita et al. (2012). Thick white lines delineate the upper surface of the subducting Pacific slab. Contours indicate P and S wave velocity values contoured at intervals of 0.6 and $0.3 \mathrm{~km} / \mathrm{s}$ in $\mathbf{b}-\mathbf{f}$ and $\mathbf{h}-\mathbf{I}$, respectively (and 0.5 and $0.25 \mathrm{~km} / \mathrm{s}$, respectively, in $\mathbf{a}, \mathbf{g}$ ). Green and green dashed ellipses in $\mathbf{a}$ and $\mathbf{g}$ indicate the locations of intrusion of the high-velocity materials. The bold horizontal lines at the top of each plot represent the land area. Triangles at the top of the plots indicate the locations of thrust faults (green: thrust (extension of Ishikari-teichi-toen fault zone), aqua blue: Yubari-dake fault, red: Hidaka main thrust, dark blue: Tokachi Plain faults, pink: Urahoro fault). The green and gray rectangles and the gray area at the top of the plot indicate the locations of the Hidaka and Kamuikotan metamorphic belts, respectively. White-shaded areas indicate portions of DWS $<500$ 

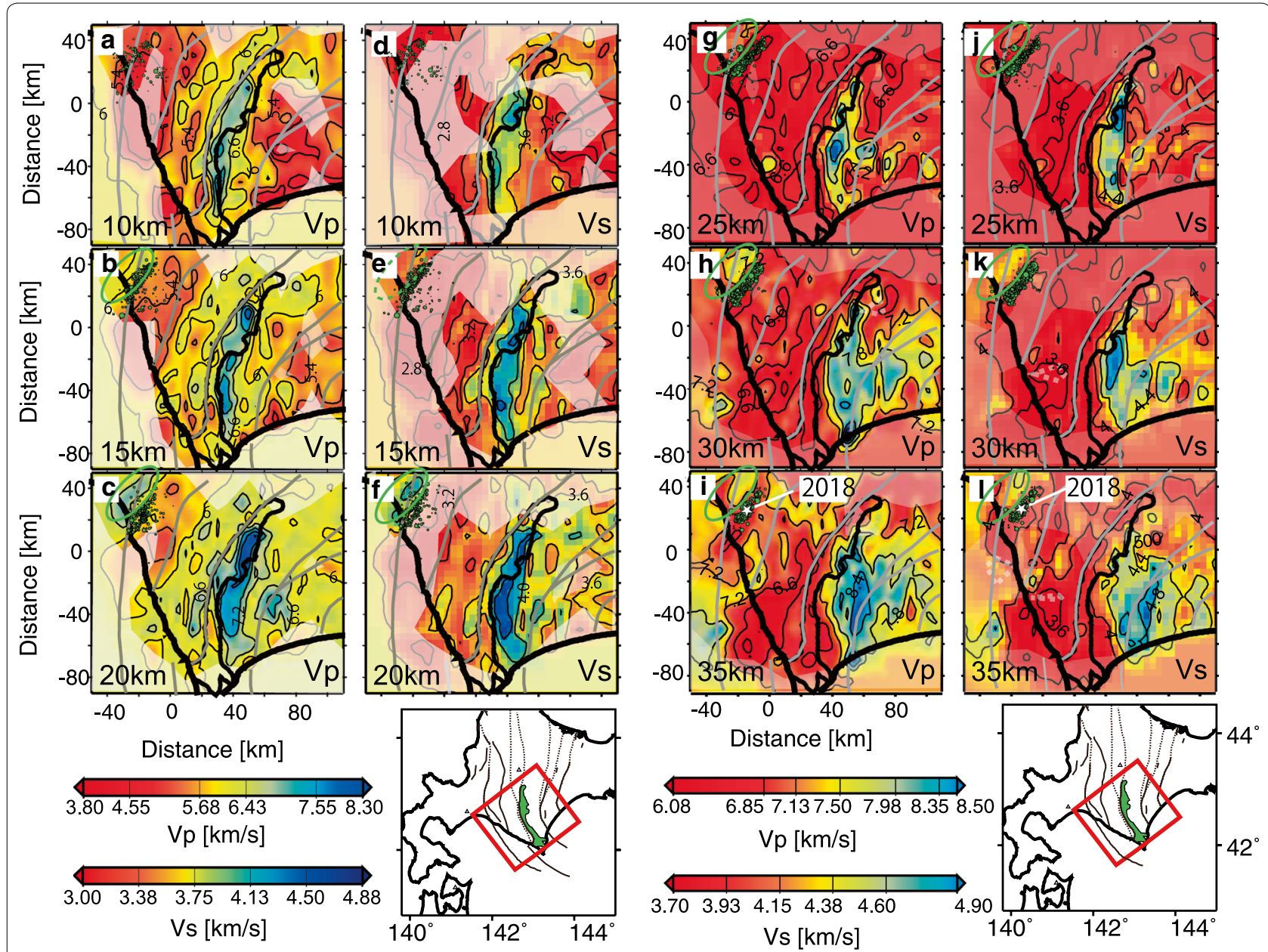

Fig. 5 Relocated hypocenters in the present study plotted on the horizontal cross-sections of P and S wave velocities estimated by Kita et al. (2012). Green dots indicate the hypocenters of aftershocks within $2.5 \mathrm{~km}$ in the depth direction, and the white stars in $\mathbf{i}$ and $\mathbf{I}$ indicate the mainshock. The $\mathrm{P}$ wave velocities are shown at depths of 10,15,20,25, 30, and $25 \mathrm{~km}$ in $\mathbf{a}-\mathbf{c}$ and $\mathbf{g}$-i, respectively. The $\mathrm{S}$ wave velocities at these depths are shown in $\mathbf{d}-\mathbf{f}$ and $\mathbf{j}-\mathbf{I}$. Note that the color scales for $\mathbf{a}-\mathbf{f}$ are different from those for $\mathbf{g}-\mathbf{I}$. Contours indicate P and $\mathrm{S}$ wave velocity values at intervals of 0.6 and $0.4 \mathrm{~km} / \mathrm{s}$, respectively. Green and green dashed ellipses indicate the location of intrusion of the high-velocity materials. Gray lines indicate the locations of thrust faults. The black area and thick black lines indicate the locations of the Hidaka metamorphic belt and the coast line, respectively. White-shaded areas indicate portions of DWS $<500$

$\mathrm{Vp}<7.0 \mathrm{~km} / \mathrm{s}$ and $\mathrm{Vs}<4.0 \mathrm{~km} / \mathrm{s}$, parallel to high-velocitymaterial $(\mathrm{Vp}>7.6 \mathrm{~km} / \mathrm{s}$ and $\mathrm{Vs}>4.2 \mathrm{~km} / \mathrm{s})$ intrusion at depths of 30 to $40 \mathrm{~km}$ (Figs. 4a, g, 5h, i, k, l). The aftershocks at depths of 10 to $20 \mathrm{~km}$ are also located parallel to high-velocity materials and the tectonic line near the Ishikari-teichi-toen fault zone (Fig. 5a-f). The mainshock and aftershocks are also plotted on the seismic attenuation structure (Kita et al. 2014) shown in Fig. 6. The aftershocks at depths of 7.5 to $22.5 \mathrm{~km}$ are clearly located at the western edge of the high-attenuation zone $(\mathrm{Qp}=300)$, which approximately corresponds to the Ishikashi-teichi-toen fault zone (Fig. 6a, b). The mainshock lies in the moderate attenuation portions (Fig. 6c, e, f).

\section{Discussion}

Ishikari-teichi-toen fault zone and the Hidada collision zone

Kita et al. (2012) indicated that a broad low-velocity zone of $\mathrm{P}$ and $\mathrm{S}$ waves, with velocities consistent with those of crustal rocks $(\mathrm{Vp}<7.2 \mathrm{~km} / \mathrm{s}, \mathrm{Vs}<4.2 \mathrm{~km} / \mathrm{s})$, was revealed west of the Hidaka main thrust at depths of $35-90 \mathrm{~km}$ (Figs. 4, 5). The Vp/Vs ratio values in this low-velocity zone ranged from 1.60 to 1.71 , suggesting that the lowvelocity zone is not serpentinized mantle wedge material, because $\mathrm{Vp} / \mathrm{Vs}$ values for serpentine are generally larger than 2.0 (Christensen 1996). In Fig. 4c through $\mathrm{f}$, the low-velocity zone (crust materials) exists at depths of 


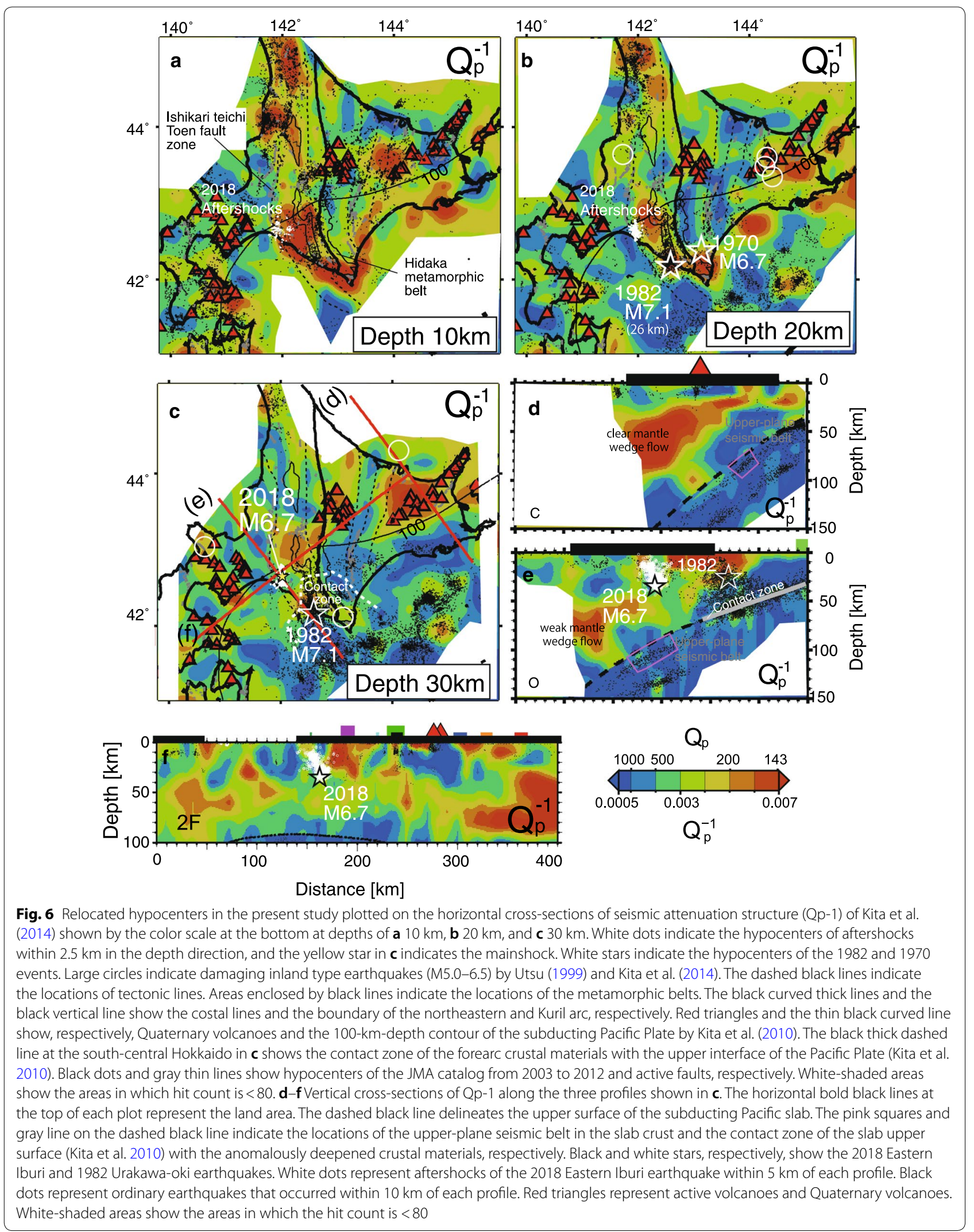


more than $40 \mathrm{~km}$ and contacted the upper surface of the subducting Pacific plate beneath the westward area of the Hidaka main thrust, whereas thickened crust materials exist at depths of less than $40 \mathrm{~km}$ in Figs. 1b, 4a and g, including the 2018 mainshock and the aftershocks. These figures showed that the aftershocks and mainshock are located on the northwestern edge of the thickened crust materials related to the Hidaka collision zone beneath the NE Japan arc. The mainshock and aftershocks also lied near the high-velocity-material intrusion $(\mathrm{Vp}>7.6 \mathrm{~km} / \mathrm{s}$ and $\mathrm{Vs}>4.2 \mathrm{~km} / \mathrm{s}$ ) (Figs. 4a, g, 5h, i, k, l), which corresponds to uppermost mantle materials (e.g., serpentine and/or peridotite (Christensen 1996).

The relocated hypocenters of the mainshock and aftershocks are generally located at depths of 10 to $40 \mathrm{~km}$ (Fig. 3b, c), striking in the north-south direction (Fig. 3a), inclined eastward at less than $60^{\circ}$ (Fig. 3b) and parallel to the high-velocity-material intrusion (Figs. 1b, 5g, h, k, l). Kita et al. (2012) found a broad low-velocity zone of $P$ and $S$ waves with velocities consistent with those of crustal rocks and also found that several small-scale high-velocity zones are located at depths of $0-35 \mathrm{~km}$ inclined northeastward at $40^{\circ}-60^{\circ}$ (Fig. 4). All of these anomalous highvelocity zones are located at deeper extensions of Neogene thrust faults (Fig. $4 \mathrm{~b}-\mathrm{d}$ and $\mathrm{h}-\mathrm{j}$, especially Fig. $4 \mathrm{~d}$ and i). Moreover, the fault planes of the 1970 M 6.7 Hidaka earthquake and the 1982 M 7.1 Urakawa-oki earthquake occur in the crust materials beneath the NE Japan arc, and are located near the sharp boundaries of this anomalous high-velocity zone and this low-velocity zone (Figs. 1c, $4 \mathrm{~d}$ in the present study, and Fig. 11 of Kita et al. (2012). Kita et al. indicated the possibility that these two events occurred through Neogene thrust faults, which penetrate from the shallower portion to the deeper portion (at least $40 \mathrm{~km}$ ) in the collision zone (Fig. 1b). They thought that these Neogene thrust faults were important to the collision process. On the other hand, the cross-sectional view in Fig. 3b shows that the $60^{\circ}$ inclined hypocenter sequence appears to be located in the deeper extension of the Ishikari-teichi-toen fault zone. The seismic attenuation structure at depths of 10, 20, and $30 \mathrm{~km}$ by Kita et al. (2014) also seems to support that the Ishikari-teichi-toen fault zone is a highly inclined fault (Fig. 6a). The highly inclined fault indicated in the present study is not inconsistent with the $74^{\circ}$ inclined fault estimated by the InSAR data analysis (Geospatial Information Authority of Japan 2018a, b; Kobayashi 2019). Since the dip of the fault is approximately the same as the dip of the sharp material boundaries in central Hidaka indicated by Kite et al., the present study suggests that the 2018 M 6.7 event occurs by means of old fracture, such as the Ishikari-teichi-toen fault zone. Geographical studies, however, reported that the fault plane of the Ishikari-teichi-toen fault zone has a low inclined dip (Earthquake Research Committee 2010). Since their study depth only covered the portion near the surface, the dip of the fault zone at a shallow depth would not be the same as the dip indicated by the present study. Gravity anomaly research reports did not show a large difference between the regions eastward and westward of the Ishikari-teichi-toen fault zone (Earthquake Research Committee 2010; Komazawa 2014), which does not clearly suggest a large previous dip slip activity. Based on a geological study, the Neogene (Miocene) thrust faults in the Hidaka collision zone, including the Ishikari-teichitoen fault zone, were originally strike faults, having a long history of strike faulting from $25 \mathrm{Ma}$ before the arc-arc collision started (12 Ma) (Maeda 1990; Kimura 1996; Kusunoki and Kimura 1998; Jolivet et al. 2018). Moreover, based on the geochemical analysis of zircon, a petrological study (Kemp et al. 2007) shows the intrusion of gabbro into the accretionary prism of the Cretaceous in the Hidada metamorphic belt occurred by the magmatism due to an asthenospheric upwelling related to the backarc spreading in the Miocene (19 Ma) (Kimura 1996). The effect on the gravity anomalies by the gabbro intrusion and strike slip faulting can be greater than that by the dip slip of the high-angle fault. The accretionary prism of the Cretaceous (130 to $100 \mathrm{Ma}$ ) consists of fractions of oceanic crust materials and thrusts. The Miocene marine sedimentary rocks are reported in the surface geology of the Eastern Iburi earthquake region in the Ishikari Lowland (Geological Survey of Japan AIST 2006) and seem to be located over the Cretaceous accretionary prism therein (e.g., Figure 1 of Ueda 2005). Geographical studies reported that the fault plane within the sedimentary rocks, but the relationship of detailed locations of the sedimentary rocks and the Cretaceous accretionary prism remains unknown. Therefore, I consider the possibility that the 2018 M6.7 event occurs by means of a fault in the crustal materials related to the Cretaceous accretionary prism beneath the Ishikari-teichi-toen fault zone. The fault possibly connects to the Ishikari-teichi-toen fault zone at deeper depths (Fig. 1b). Near the Ishikari-teichitoen fault zone, other small faults are also located in the deeper extension of the aftershocks hypocenters of the 2018 event. Using data from the Daichi-2 satellite, the Geospatial Information Authority of Japan shows that the pattern of the InSAR clearly changed beneath the eastern region of the Ishikari-teichi-toen fault zone (westward of the epicenter of the mainshock of the 2018 event) in the NNW-SSE direction (Earthquake Research Committee 2018), although the problem of less sensitivity of INSAR for a deeper part of the rupture must not be neglected. The gravity anomaly pattern (Komazawa 2014) is also changed at the boundary of the InSAR pattern, which corresponds to locations of the Atsuma fault (Kimura 2019) 
and the Atsuma syncline reported by Matsuno and Ishida (1960). A recent reflection study reports the fault plane of the Atsuma fault inclined eastward and the dip was $\sim 60^{\circ}$ at depths of $\sim 1 \mathrm{~km}$ and $\sim 20^{\circ}$ at depths of more than $2 \mathrm{~km}$ (Kozuka et al. 2002). The location of the Atsuma fault is shown in Fig. 3a. Further discussion of the 2018 event along local geoscientific characteristics is intended as an area for future study.

Based on not only the geological evidences, but also the results of geodetic studies using triangulation/trilateration data during several decades (e.g., Tada and Kimura 1987), Kimura (1986, 1996) proposed that the Kuril forearc sliver in the southeastern Hokkaido is moving southwestward and has been colliding with the NE Japan arc at the Hidaka collision zone since $12 \mathrm{Ma}$. Recently, our understanding of crustal deformation before, during and after large earthquakes has been greatly improved by Global Navigation Satellite System (GNSS) observations with the improved temporal resolution from conventional geodetic observations such as triangulation/trilateration. Interseismic north-westward deformation of the forearc regions in Hokkaido recently observed by GNSS has been mainly explained by deformations due to locking between the continental and Pacific plates (Ito et al. 2000; Suwa et al. 2006; Hashimoto et al. 2009; Itoh et al. 2019). A block model assuming the Kuril forearc sliver as well as interplate locking did not fit the recent GNSS data well, either (Loveless and Meade 2010). The Kuril forearc sliver migration indicated by the geological studies could be presently small enough to be hidden by deformation due to the interplate locking, which may be related to the reason why large gravity anomalies are not reported beneath the Eastern Iburi earthquake region.

Figure 5 shows the horizontal sections of seismic structures, indicating also that the hypocenter sequence of the mainshock and aftershocks was located in the anomalous deep forearc crust materials. The hypocenter sequence was also located parallel to the sharp boundary of the crust and mantle materials at depths of 30 to $35 \mathrm{~km}$ (green ellipse in Fig. 5h, i, k, l), and also located parallel to high-velocity crust materials at depths of 15 to $25 \mathrm{~km}$ (green ellipse in Fig. 5b, c, e, f, g, j). Although the high-velocity-material intrusion with velocities of uppermost mantle materials westward of the hypocenter sequence is very small, the restoring resolution test (Zhao et al. 1992) by Kita et al. (2012) has shown that this intrusion structure of high-velocity materials is believable (Fig. 5 in Kita et al. 2012). The western edge of the low $\mathrm{Qp}(\mathrm{Qp}=300)$ in the Hidaka collision zone corresponds to the Ishikari-teichi-toen fault zone at depths of 10 and $20 \mathrm{~km}$, at which the aftershocks of the 2018 events are located (Fig. 6a, b). Therefore, the main shock and aftershocks occurred in the crust material, but using the sharp material boundaries between the uppermost mantle and crustal materials (Fig. 1b). This kind of relationship between the hypocenters and material distributions is the same as that of the 2018 M6.7 event, and the 1970 and the 1982 events in the Hidaka collision zone. Oman ophiolite studies have shown that dunite of several hundred meters in width, which is easily deformed compared to other peridotite rocks due to the weakest crystal structure among them, is always reported in the Moho transition zone of the Oman ophiolite (e.g., Boudier and Nicolas 1995; Jousselin et al. 1998). The velocities of the uppermost mantle material intrusion near the fault of the Iburi eastern earthquake are slightly smaller than those of dunite (Christensen 1996), but strain may accumulate on the material boundaries of uppermost mantle and crust materials near the main shock before the beginning of the rupture of the mainshock, which could be a trigger of the mainshock.

\section{Cause of the great depth and heat flow studies}

The mainshocks of the 2018 M6.7 event and the 1970 and the 1982 events in the Hidaka collision zone have a greater depth than typical inland earthquakes in the Japan archipelago. Since the greater depth limit of inland earthquake is generally related to weakening the temperature of quartz, a locally low temperature beneath and north-westward of the Hidaka collision zone could cause anomalous deep large-magnitude events.

Studies of the heat flow and the geothermal gradient in the Japan archipelago compiled by Tanaka (2004) show locally very low values in south-central Hokkaido, as compared with those in the surrounding area (Fig. 7). In the Hokkaido corner, several seismological observations also support the locally low-temperature structure: the peak depth of seismicity in the subducting oceanic crust (the upper-plane seismic belt), which

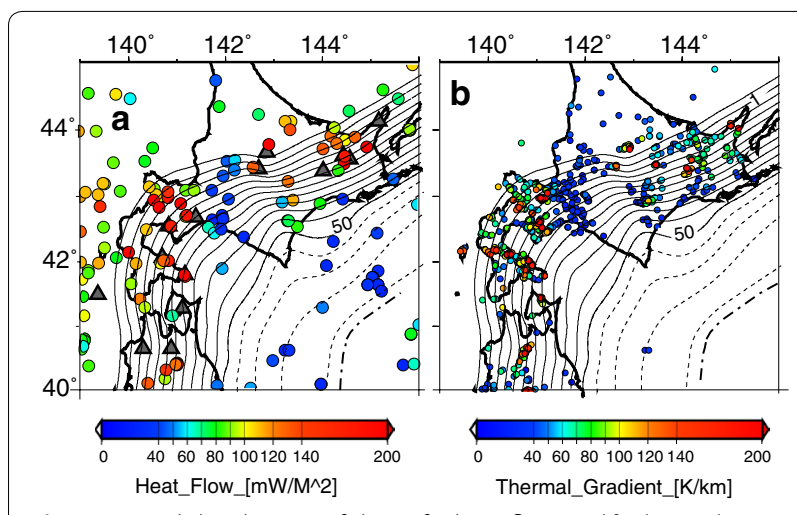

Fig. 7 Spatial distribution of data of $\mathbf{a}$ heat flow and $\mathbf{b}$ thermal gradient by Tanaka (2004). Color scales are shown at the bottom of the figures 
is due to the eclogite-forming phase change with dehydration, is locally deepened there $(\sim 120 \mathrm{~km})$ (Kita et al. 2010) (pink square in Fig. 6e), whereas that in Tohoku and east Hokkaido is approximately $80 \mathrm{~km}$ (Kita et al. 2006) (pink square in Fig. 6d). The deeper limits of the low-angle thrust faults and repeating earthquakes are locally deepened $(\sim 70 \mathrm{~km})$ at this location, whereas these limits are approximately $60 \mathrm{~km}$ in Tohoku and approximately $50 \mathrm{~km}$ in east Hokkaido (Kita et al. 2010; Uchida et al. 2003). The locally low temperature occurs because the anomalous deep Kuril forearc crust materials contact the surface of the subducting oceanic plate due to the collision with the NE Japan arc (Kita et al. 2010) and avoid the mantle wedge flow to contact to the subducting slab at depths of the contact zone of the crust materials (Figs. 1a, c, 4c-f, j-l, 6c, e, 7). The mantle wedge flow, which is the return flow against the subduction of the oceanic plate, becomes weaker beneath the north-westward of the Hidaka collision zone compared to the flow beneath surrounding areas [Fig. $6 \mathrm{~d}$, e in the present study and Fig. 16 of Kita et al. (2014)]. A seismic attenuation study also shows that a clear low-attenuation structure above the slab, which is considered to be mantle wedge flow, is located in the mantle wedge beneath eastern (Fig. 6d) and southern Hokkaido, whereas this structure was not located beneath the north-westward of the Hidaka collision zone (Fig. 6e).

\section{Commonality with damaging inland crustal earthquakes in Hokkaido}

Damaging inland crustal earthquakes at depths of 10 to $30 \mathrm{~km}$ in Hokkaido reported by Utsu (1999) and Kita et al. (2014) are shown in Fig. 6. Most of these events are located at the edge of the low-Q zone $(\mathrm{Qp}<166)$. The 2018 event itself is located in a mid-Qp zone, but close to the low-Qp part of the Hidaka collision zone. The surrounding areas of the low-Qp zone may experience future damaging earthquakes.

\section{Conclusion}

I relocated the hypocenters of microearthquakes, including the aftershocks and mainshock of the 2018 M6.7 inland type event in south-central Hokkaido, using a high-resolution three-dimensional seismic velocity structure. The results of the relocation show that the aftershocks are generally relocated at depths ranging from 10 to $40 \mathrm{~km}$, and the focal depth of the mainshock changed from $37.0 \mathrm{~km}$ to $35.4 \mathrm{~km}$ after the relocation. The relocated hypocenters of the mainshock and aftershocks were located in the anomalous deep forearc crust materials beneath the northwestern edge of the Hidaka collision zone. Like the previous two large events in the collision zone, the focal depth of the mainshock is located in the crust materials parallel to the uppermost mantle intrusions beneath the NE Japan forearc and is anomalously larger than the average inland crustal earthquakes beneath the Japanese archipelago. These large events have a role in the ongoing collision zone process. These anomalously large focal depths were caused by the locally low temperature reported in southcentral Hokkaido.

The fault plane was approximately $60^{\circ}$ inclined and appears to be located in the deeper extension of the Ishikari-teichi-toen fault zone. The aftershocks of the 2018 event also lie in the western edge of the highattenuation zone, parallel to the Ishikari-teichi-toen fault zone. Like the previous two events, the 2018 M6.7 event occurred using one of material boundaries, which could be related with one of old thrust (dip slip) faults like the Ishikari-teichi-toen fault zone, though the detailed relationship between the thrust fault reported on the surface and the 2018 event has been still unknown.

The previous seismological studies have thought that the anomalously deep crustal materials, in which the 2018 M6.7 and previous two events occurred, are mainly formed by the arc-arc collision process. Not only the collision process itself but also the geological processes before the collision could be related with the formation of the thickened crust. Consideration of this geological history is needed for understanding the present observation results of seismological, geodetic, geological, petrological and geographical studies and revealing the overall of the Hidaka collision zone process.

\section{Supplementary information}

Supplementary information accompanies this paper at https://doi. org/10.1186/s40623-019-1100-0.

Additional file 1. Seismic velocities structure used in this study.

Additional file 2. Hypocenter parameters of relocated earthquakes of the main shock and its aftershocks.

\section{Acknowledgements \\ I would like to thank Yuji Itoh, Asuka Yamaguchi, Gaku Kimura, Eiichi Takazawa, Makoto Matsubara, Akira Hasegawa and Toru Matsuzawa for the helpful dis- cussions. I also thank the anonymous reviewers for beneficial and constructive comments and editors for the review process of my paper.}

\section{Authors' contributions}

This paper has only one author, Saeko Kita, who processed the seismological data, determined hypocenters, made all figures and wrote this paper.

\section{Funding}

This study was also supported by the Japan Society for the Promotion of Science (JSPS) through Grants-in-Aid for Scientific Research 17K05637, 25800243 and 23740329. 


\section{Availability of data and materials}

The arrival time data and hypocenter parameters analyzed in this study were obtained from the Kiban seismic networks (http://www.hinet.bosai.go.jp/) of the Japan Meteorological Agency (JMA), the National Research Institute for Earth Science and Disaster Prevention (Hi-net), Hokkaido University and Hirosaki University.

\section{Competing interests}

The author declares that they have no competing interests.

Received: 1 May 2019 Accepted: 27 October 2019

Published online: 14 November 2019

\section{References}

Boudier F, Nicolas A (1995) Nature of the Moho transition zone in the Oman ophiolite. J Petrol 36:777-796

Christensen NI (1996) Poisson's ratio and crustal seismology. J Geophys Res 101:3139-3156. https://doi.org/10.1029/95JB03446

Earthquake Research Committee (2010) Evaluation of the Ishikari-teichi-toen fault zone (published on August 26, 2010) (in Japanese)

Earthquake Research Committee (2018) The 2018 Hokkaido Eastern Iburi Earthquake-Distribution of Crustal Deformation by "Daichi-2" (2.5 Dimensional Analysis) (provisional). Evaluation of the 2018 Hokkaido Eastern Iburi Earthquake (published September 11, 2018) https://www. jishin.go.jp/main/chousa/18sep_iburi2/p10-e.htm

Fuji S, Moriya T (1983) Upper crustal structure in the Hidaka district by refraction measurements using the quarry blasts [in Japanese with English abstract and figure captions]. Geophys Bull Hokkaido Univ 42:169-190

Furumura T, Moriya T (1990) Three-dimensional Q structure in and around the Hidaka mountains, Hokkaido, Japan, [in Japanese with English figure captions]. J Seismol Soc Jpn 43:121-132

Geological Survey of Japan (1992) Geological Atlas of Japan, 2nd edn. Asakura, Tokyo

Geological Survey of Japan, AIST (2006) Surface Geology of Sapporo and its Surroundings, Hokkaido, Scale 1:30,000, Digital Geoscience Map Series G-14 (CD-ROM)

Geospatial Information Authority of Japan (2018a) The 2018 Hokkaido Eastern Iburi earthquake: Fault model (preliminary) http://www.gsi.go.jp/cais/ topic180912-index-e.html

Geospatial Information Authority of Japan (2018b) The 2018 Hokkaido Eastern Iburi earthquake: Fault model (preliminary). Report of 221th meeting of the Coordinating Committee for Earthquake Prediction, pp 29-31 (in Japanese)

Hashimoto C, Noda A, Sagiya T, Matsu'ura M (2009) Interplate seismogenic zones along the Kuril-Japan trench inferred from GPS data inversion. Nat Geosci 2:141-144

Ichikawa M (1971) Reanalysis of the mechanisms of earthquakes which occurred in and near Japan and statistical studies on the nodal plane solutions obtained, 1926-1968. Geophys Mag 35:207-273

Ito T (2000) Crustal structure of the Hidaka collision zone and its foreland foldand-thrust belt, Hokkaido, Japan [in Japanese with English abstract]. J Jpn Assoc Pet Technol 65:103-109. https://doi.org/10.3720/japt.65.103

Ito T et al (1999) Delamination wedge structure beneath the Hidaka collision zone [in Japanese]. Chikyu Mon 21(3):130-136

Ito T, Yoshioka S, Miyazaki S (2000) Interplate coupling in northeast Japan deduced from inversion analysis of GPS data. Earth Planet Sci Lett 176(1):117-130

Itoh Y, Nishimura T, Ariyoshi K, Matsumoto H (2019) Interplate slip following the 2003 Tokachi-oki earthquake from ocean bottom pressure gauge and land GNSS data. J Geophys Res. https://doi.org/10.1029/2018JB016328

Iwasaki T, Ozel O, Moriya T, Sakai S, Suzuki S, Aoki G, Maeda T, lidaka T (1998) Lateral structural variation across a collision zone in central Hokkaido, Japan, as revealed by wide-angle seismic experiments. Geophys J Int 132:435-457. https://doi.org/10.1046/j.1365-246x.1998.00454.x

Iwasaki T, Adachi K, Moriya T, Miyamachi H, Matsushima T, Miyashita K, Takeda T, Taira T, Yamada T, Ohtake K (2004) Upper and middle crustal deformation of an arc-arc collision across Hokkaido, Japan, inferred from seismic refraction/wide-angle reflection experiments. Tectonophysics 388:59-73. https://doi.org/10.1016/j.tecto.2004.03.025
Jolivet L, Faccenna C, Becker T, Tesauro M, Sternai P Bouilhol P (2018) Mantle flow and deforming continents: from India-Asia Convergence to Pacific subduction. Tectonics 37:2887-2914. https://doi.org/10.1029/2018T C005036

Jousselin D, Nicolas A, Boudier F (1998) Detailed mapping of a paleo-spreading center in the Oman ophiolite. J Geophys Res 103:18153-18170

Katsumata K et al (2002) Distribution of hypocenters and focal mechanisms in and around the Hidaka arc-arc collision zone revealed by a dense temporary seismic network [in Japanese]. Bull Earthquake Res Inst Univ Tokyo 77:199-223

Katsumata K, Wada N, Kasahara M (2003) Newly imaged shape of the deep seismic zone within the subducting Pacific plate beneath the Hokkaido corner, Japan-Kurile arc-arc junction. J Geophys Res 108(B12):2565. https //doi.org/10.1029/2002JB002175

Katsumata K, Wada N, Kasahara M (2006) Three-dimensional P and S wave velocity structures beneath the Hokkaido corner, Japan-Kurile arc-arc junction. Earth Planets Space 58:e37-e40. https://doi.org/10.1186/BF033 52595

Kemp AIS, Shimura T, Hawkesworth CJ, EIMF (2007) Linking granulites, silicic magmatism, and crustal growth in arcs: ion microprobe (zircon) U-Pb ages from the Hidaka metamorphic belt, Japan. Geology 35(9):807-810. https://doi.org/10.1130/G23586A.1

Kimura G (1986) Oblique subduction and collision: forearc tectonics of the Kuril arc. Geology 14:404-407

Kimura G (1994) The latest Cretaceous-early Paleogene rapid growth of accretionary complex and exhumation of high pressure series metamorphic rocks in northwestern Pacific margin. J Geophys Res 99:22147-22164. https://doi.org/10.1029/94JB00959

Kimura G (1996) Collision orogeny at arc-arc junctions in the Japanese Islands, Isl. Arc 5:262-275. https://doi.org/10.1111/j.1440-1738.1996.tb00031.x

Kimura G (2019) Personal communication

Kita S, Okada T, Nakajima J, Matsuzawa T, Hasegawa A (2006) Existence of a seismic belt in the upper plane of the double seismic zone extending in the along-arc direction at depths of 70-100 km beneath NE Japan. Geophys Res Lett 33:L24310. https://doi.org/10.1029/2006gl028239

Kita S, Okada T, Hasegawa A, Nakajima J, Matsuzawa T (2010) Anomalous deepening of a seismic belt in the upper-plane of the double seismic zone in the Pacific slab beneath the Hokkaido corner: possible evidence for thermal shielding caused by subducted forearc crust materials. Earth Planet Sci Lett 290:415-426. https://doi.org/10.1016/j.epsl.2009.12.038

Kita S, Hasegawa A, Nakajima J, Okada T, Matsuzawa T, Katsumata K (2012) High-resolution seismic velocity structure beneath the Hokkaido corner, northern Japan: arc-arc collision and origins of the 1970 M-6.7 Hidaka and 1982 M-7.1 Urakawa-oki earthquakes. J Geophys Res 117:B12301. https://doi.org/10.1029/2012jb009356

Kita S, Nakajima J, Hasegawa A, Okada T, Katsumata K, Asano Y, Kimura T (2014) Detailed seismic attenuation structure beneath Hokkaido, northeastern Japan: arc-arc collision process, arc magmatism, and seismotectonics. J Geophys Res Solid Earth 119:6486-6511. https://doi.org/10.1002/2014J B011099

Kobayashi T, Hayashi K, Yarai H (2019) Geodetically estimated location and geometry of the fault plane involved in the 2018 Hokkaido Eastern Iburi Earthquake, submitted to EPS (under revision)

Komazawa M, Okuma S, Joshima M (2014) Explanatory notes of 1:200,000 gravity map of the Ishikari Depression and its surrounding area (Bouguer Anomalies). Seamless Geoinformation of Coastal Zone "Southern Coastal Zone of the Ishikari Depression"S-4 (DVD), Geological survey of Japan, AIST

Kozuka T, Kikuchi S, Ito T (2002) Structure of the foreland fold-and-thrust belt, Hidaka collision zone, Hokkaido, Japan: re-processing and re-interpretation of the JNOC seismic reflection profiles 'Hidaka' (H91-2 and H91-3). Bull Earthq Res Inst Univ Tokyo 77:97-109

Kusunoki K, Kimura G (1998) Collision and extrusion at the Kuril-Japan arc junction. Tectonics 17(6):843-858. https://doi.org/10.1029/98TC02699

Loveless JP, Meade BJ (2010) Geodetic imaging of plate motions, slip rates, and partitioning of deformation in Japan. J Geophys Res 115:B02410. https:// doi.org/10.1029/2008JB006248

Maeda J (1990) Opening of the Kuril Basin deduced from the magmatic history of Central Hokkaido, North Japan. Tectonophysics 174(3-4):235-255

Matsuno K, Ishida M (1960) Explanatory text of the geological map of Japan Scale 1:50,000, Hayakita (Sapporo, No. 43), Hokkaido Development 
Agency, p 35 (in Japanese) https://www.gsj.jp/data/50KGM/PDF/GSJ_ MAP_G050_04043_1960_D.pdf

Miyamachi H, Moriya T (1984) Velocity structure beneath the Hidaka Mountains in Hokkaido, Japan. J Phys Earth 32:13-42. https://doi.org/10.4294/ jpe1952.32.13

Miyamachi H, Kasahara M, Suzuki S, Tanaka K, Hasegawa A (1994) Seismic velocity structure in the crust and upper mantle beneath northern Japan. J Phys Earth 42:269-301. https://doi.org/10.4294/jpe1952.42.269

Moriya T (1972) Aftershock activity of the Hidaka Mountains earthquake of January 21, 1970 [in Japanese with English figure captions]. J Seismol Soc Jpn 24:287-297

Moriya T, Miyamachi H, Katoh S (1983) Spatial distribution and mechanism solutions for foreshocks, mainshock an aftershocks of the Urakawa-oki Earthquake of March 21, 1982 [in Japanese with English figure captions]. Geophys Bull Hokkaido Univ 42:191-213

Moriya T, Okada H, Matsushima T, Asano S, Yoshii T, Ikami A (1998) Collision structure in the upper crust beneath the southwestern foot of the Hidaka Mountains, Hokkaido, Japan as derived from explosion seismic observations. Tectonophysics 290:181-196. https://doi.org/10.1016/50040 $-1951(98) 00011-0$

Murai Y et al (2003) Delamination structure imaged in the source area of the 1982 Urakawa-oki earthquake. Geophys Res Lett 30(9):1490. https://doi. org/10.1029/2002GL016459

Obara K, Kasahara K, Hori S, Okada Y (2005) A densely distributed high-sensitivity seismograph network in Japan: Hi-net by National Research Institute for Earth Science and Disaster Prevention. Rev Sci Instrum 76:021301. https://doi.org/10.1063/1.1854197

Okada Y, Kasahara K, Hori S, Obara K, Sekiguchi S, Fujiwara H, Yamamoto A (2004) Recent progress of seismic observation networks in Japan-Hi-net, F-net, K-NET and KiK-net. Res News Earth Planets Space 56:15-28

Omuralieva AM, Hasegawa A, Matsuzawa T, Nakajima J, Okada T (2012) Lateral variation of the cutoff depth of shallow earth- quakes beneath the Japanese Islands and its implications for seismogenesis. Tectonophysics 518-521:93-105. https://doi.org/10.1016/j.tecto.2011.11.013

Suwa Y, Miura S, Hasegawa A, Sato T, Tachibana K (2006) Interplate coupling beneath NE Japan inferred from three-dimensional displacement field. J Geophys Res 111:B04402. https://doi.org/10.1029/2004JB003203
Tada T, Kimura G (1987) Collision Tectonics and Crustal deformation at the southwestern margin of the Kurile arc. J Seismol Soc Jpn 40(2):197-204

Taira T, Yomogida K (2004) Imaging of three-dimensional small-scale heterogeneities in the Hidaka, Japan region: coda spectral analysis. Geophys J Int 158:998-1008. https://doi.org/10.1111/j.1365-246X.2004.02333.x

Takahashi T (2012) Three-dimensional attenuation structure of intrinsic absorption and wide-angle, scattering of $\mathrm{S}$ waves in northeastern Japan. Geophys J Int 189:1667-1680

Takanami T (1982) Three-dimensional seismic structure of the crust and upper mantle beneath the orogenic belts in southern Hokkaido, Japan. J Phys Earth 30:87-104. https://doi.org/10.4294/jpe1952.30.87

Tanaka A (2004) Geothermal gradient and heat flow data in and around Japan (II): crustal thermal structure and its relationship to seismogenic layer. Earth Planets Space 56:1195-1199. https://doi.org/10.1186/BF03353340

Uchida N, Matsuzawa T, Hasegawa A, Igarashi T (2003) Interplate quasi-static slip off Sanriku, NE Japan, estimated from repeating earthquakes. Geophys Res Lett 30(15):1801. https://doi.org/10.1029/2003GL017452

Ueda $\mathrm{H}$ (2005) Accretion and exhumation structures formed by deeply subducted seamounts in the Kamuikotan high-pressure/temperature zone, Hokkaido, Japan. Tectonics 24:2007. https://doi.org/10.1029/2004t c001690

Utsu T (1999) Seismicity studies: a comprehensive review [in Japanese]. Univ of Tokyo Press, Tokyo, p 876

Zhang H, Thurber CH (2003) Double-difference tomography: the method and its application to the Hayward fault, California. Bull Seismol Soc Am 93:1875-1889

Zhang H, Thurber CH (2006) Development and applications of double-difference seismic tomography. Pure Appl Geophys 163:373-403

Zhao D, Hasegawa A, Horiuchi S (1992) Tomographic imaging of P and S wave velocity structure beneath northeastern Japan. J Geophys Res 97:19909-19928. https://doi.org/10.1029/92JB00603

\section{Publisher's Note}

Springer Nature remains neutral with regard to jurisdictional claims in published maps and institutional affiliations.

\section{Submit your manuscript to a SpringerOpen ${ }^{\circ}$ journal and benefit from:}

- Convenient online submission

- Rigorous peer review

- Open access: articles freely available online

- High visibility within the field

- Retaining the copyright to your article

Submit your next manuscript at $\boldsymbol{\nabla}$ springeropen.com 